\title{
Media representations of The Intoxicated
}

\author{
Authors \\ Tammy Ayres, University of Leicester, UK \\ Stuart Taylor, Liverpool John Moores University, UK
}

\begin{abstract}
This chapter examines media representations of intoxication in the context of neoliberal consumer capitalism. It illustrates how the media ideologically function in maintaining the capitalist status quo whilst distracting attention from the paradoxical nature and embedded systemic harms of consumerism. Looking at the media through a Žižekian lens, we identify how the intoxicated are constructed as representing a threat to our way of life through their irresponsible, flawed and uncivilised consumption practices. As such, the media partakes in objective violence through its purposeful polarisation of intoxication practices: ensuring the condemnation, alienation and criminalisation of the barbaric consumer; and the celebration and social recognition of the civilised.
\end{abstract}

\section{Introduction}

The neo-liberal era of consumer capitalism sees engagement with consumer markets and the consumption of goods mediating all aspects of social life. Resultantly, the health, economic, environmental and indeed moral good of society are entwined with who consumes what, how they consume it, and the resultant ends of such practices. Consumers are provided with the freedom to choose from an array of products and as responsible agents of choice are left to navigate their own consumption. Such liberty, however, proves problematic when consumers make the wrong choices (Bauman, 1997). For example, a Friday night take away is a gastronomic treat yet those who continually eat fatty or sugary foods causing obesity and tooth decay prompt concern. A Cuban cigar at a wedding distinguishes the occasion as a special celebration yet smoking forty cigarettes a day causing lung cancer evokes worry. 
Taking opioid painkillers as a form of treatment can be a medical necessity, while injecting illegal heroin warrants arrest.

Whilst consumer-based lifestyle choices offer us apparent freedom, this freedom is illusionary. Instead, the entrepreneurial self is held accountable for our consumption choices, ergo our own fate. Freedom to choose, therefore, is only given 'on condition that you make the right choices; you are given freedom on the condition that you will not really use it' (Žižek, 2008 p129). Thus construed, freedom represents 'a formal gesture of consent to our own oppression and exploitation' (Žižek, 2008 p147), as both desire and choice are structured and controlled by capitalism and its effectual mass media. In true neoliberal ethos, those who step outside the accepted parameters of freedom become socially excluded, flawed consumers who 'deserve everything they get' for failing to adhere to the sociocultural norms that sublimate the systemic violence of consumer capitalism (Ayres, 2019; Raymen \& Smith, 2016; Žižek, 2008).

Intoxication by its very nature centres upon consumption. Whilst the consumption of drugs has been constant within every civilization throughout history, the social reaction to such use has been open to fluctuation; fluctuations tied to the exigencies and advancement of capitalism (Chambliss, 1977; Pryce, 2012). Hence, at certain times, certain intoxication practices are embraced whilst others arouse alarm and denunciation (Bancroft, 2009). In this chapter, we seek to explore the socio-cultural framing of intoxication through the lens of news media representations. In doing so, we contemplate how intoxication relates to neo-liberal notions of (ir)responsibility and (im)morality in the context of capital consumerism and how the media representation of intoxication constitutes a form of objective violence (Žižek, 2008).

We employ a straightforward definition of intoxication here - a state of non-sobriety purposely achieved through the consumption of any drug - which enables us to consider intoxication that relates to both legal and illegal substance use. Importantly, rather than concentrating on intoxication per se, the focus of this chapter is on the media emphasised social object of the intoxicated. We argue that media representations of the intoxicated fit within a wider individualistic consumer responsibilisation agenda, which serves to camouflage the underpinning tensions and contradictions of capitalism. Simultaneously, these media 
representations reinforce the apartheid between acceptable and unacceptable intoxication practices (Taylor, Buchanan \& Ayres, 2016), constructing substance use as both socially embedded, even desirable, and concurrently problematic. This agenda allows the identification of the purposeful consumer majority whose right to engage in appropriate intoxication is a marker of cultural competence, whilst simultaneously framing the intoxicated minority as consumers who lack rational judgement and warrant concern.

Through drawing primarily on news media representations of intoxication, this chapter concludes that the objective violence of the media serves to marginalise and criminalise flawed consumption practices; responsibilise the intoxicated for a plethora of social ills; and disavow the harmful practices of consumer capitalism. Whilst the chapter predominantly draws upon research and experiences from the UK, the key points have relevance to all Westernised consumer states.

\section{Media representations of the intoxicated}

Substance use is framed through a narrow reductionist drugs discourse whereby governmental rhetoric, empirical research, public knowledge and media representations revolve around the same, tapered array of issues (Taylor, 2016). Understanding the dominant media themes representing substance use is therefore crucial as they mirror the themes evident in wider political/public dialogue (Taylor, 2008). Both discursive and visual news media representations of substance use predominantly focus on detrimental anti-social, criminal, economic and health related outcomes (Ayres \& Jewkes, 2012; Hilton, Wood, Patterson \& Katikireddi, 2014). Interestingly, whilst depictions of illicit drug users centre upon notions of addiction (Alexandrescu, 2018; UKDPC, 2010), media portrayals of alcohol have moved away from primarily being concerned with dependence, towards a series of pathologized problematic modes of alcohol consumption (Nicholls, 2011) - all of which, emphasise the dangers associated with a failure to self-regulate one's freedoms (e.g. alcohol related disease, anti-social behaviour, physical and mental ill-health). Significantly, rather than media representations considering the diversity of populations engaged in such risky practices, problematic consumption is disproportionately embodied within a generic typology - that of the irresponsibly intoxicated (binge drinking) consumer. For example, each New 
Year's Day the UK's most popular newspaper, the Daily Mail, greets readers with a familiar headline;

New year, same old binge Britain: Arctic weather fails to stop drunken revellers causing chaos on streets of UK (Levy, 2010).

Welcome to 2013: Shameful scenes of booze-fuelled New Year's chaos in cities across Britain (O'Hare, 2013).

New Year... depressingly familiar scenes: Festivities are marred by drunken revellers causing chaos in towns and cities across Britain (Robinson, 2014).

New Year, but the same old shocking scenes: Mayhem in streets across Britain as drunken revellers lose their senses (Tomkin, 2016).

Some people won't be having a happy new year! Carnage on the streets of Britain as revellers see in 2017 with a night of fighting, vomiting and a LOT of flesh on show (Burrows, 2017).

Happy SPEW Year! Britons see in 2018 with a night of drunken revelry and plenty of flesh on show - followed by violence and lashings of regret as celebrations turn to carnage (Tahir, 2018a).

Such representations provide a fetishistic insight to armchair readers of the ubiquitous nightlife landscape that appears after dark in most Western nations. In the UK, this is a landscape worth nearly 6\% of Gross Domestic Product (NTIA, 2015), the majority of which comes from consumers drinking at risky levels (Bhattachary et al., 2018; Sheron \& Gilmore, 2016). Central to these media depictions is intoxication, in the form of binge drinking and drunken revelry, which is presented as both a given and as problematic (Patterson, Emslie, Mason, Fergie \& Hilton, 2016). Written into these scripts are concerns around violence, crime, vulnerability, health and economic consequences. Following the moral panic tradition, the intoxicated are framed as a symbolic social other with a breakdown of moral virtue posing a risk to the normative social order (Critcher, 2011) - a process which sees the UK news media preoccupied by an irresponsible minority of uncivilized binge drinkers whose behaviours 'are blamed for a range of both intentional and unintentional harms to 'others' through their 'alcohol-fuelled' anti-social behaviour' (Wood, Patterson, Katikireddi \& Hilton, 2014, p.580). 
Here the intoxicated binge drinker is framed as representing a risk to us (Taylor, 2016) through their 'chaos' and 'carnage' in the orderly society of 'normal' consumers who make the 'right' choices (Bauman, 2007). However, alongside the normative set of harmful risks presented to us by this group (e.g. physical violence, anti-social behaviour, burdens on health and emergency services), we see a new paradigm of risk subtlety emerging - that of a threat to our consumer freedoms. Irresponsible drinkers who cross the divide between acceptable and unacceptable consumption are seen as lacking restraint. As a potential risk to our consumer experience, not only in a direct physical sense, but also in terms of prospective restrictions on the consumer marketplace itself which spoil the fun of non-flawed consumers (Bauman, 2007). For example, policies of minimum unit alcohol pricing in the UK are framed as punishing 'the vast majority of responsible drinkers of cheap alcohol for the actions of problem drinkers' (Bourne, 2012, p.1) as there is 'no such thing as problem drinks, only problem drinkers' (McArdle, 2018, p.2).

Consequently, there is a framing of the intoxicated as bad apples who are unable to engage with consumer markets in an appropriate fashion. For example, Hilton et al. $(2014, p .3)$ indicate that the legislative decision to ban smoking in cars with children present in the UK was framed by the media as necessary due to 'thoughtless', 'seriously bad' and 'selfish' parental consumption practices. Meanwhile the role of commercial enterprise is side-lined, such as the aggressive marketing of alcohol or the sexist promotional practices of night-time leisure venues (Gunby, Carline \& Taylor, 2017). Consequently, the intoxication practices and individual choices of consumers, rather than the nature of the consumer market that encourages hedonism and excess, attracts condemnation (Smith, 2014; Winlow \& Hall, 2016). Importantly, media representations of the intoxicated cluster around common demographical profiles regardless of what substance they consume. Measham and Moore (2008, p.280) observe that problematic drinking 'may be less of a question of intoxication, than of who is drunk and where they are drunk'. Hence the media use the who and where as indicators of concerning, dysfunctional consumption. Consequently, alcohol intoxicated women are framed as acting outside of the prescribed boundaries of femininity (Day, Gough \& McFadden, 2004; Griffin et al., 2012; Hutton, Griffin, Lyons, McCreanor \& Niland, 2016), whilst intoxicated working class females are viewed with 'visceral disgust' (Lennox, Emslie, Sweeting \& Lyons, 2018, p.19). Similarly, intoxicated working class male drinkers are seen as a dysfunctional 
element of 'rough youth' (Measham \& Moore, 2008, p.284) whose 'living for the weekend' philosophy and violent tendencies appear at odds with the work hard, keep your nose clean mentality of conservative life (Tomsen, 1997; Winlow \& Hall, 2006). Additionally, whilst bar going male and female binge drinkers are essential to the night-time economy (NTE), intoxicated street drinkers are actively excluded from these spaces (Measham \& Brain, 2005).

Such depictions of the legally intoxicated integrate with characterisations of illegal drug users with the media differentiating between recreational middle-class drug users risking their productive, pro-social status and working class 'addicts' whose use represents one of a number of ingrained characteristics relating to non-productivity (Alexandrescu, 2018). Here dysfunctionality is emphasised around classed notions of an inability (or unwillingness) to work, a lack of education, links to criminality and addiction (Taylor, 2008). Indeed, within a neo-liberal context, the illegally intoxicated are framed as a redundant population (Alexandrescu, 2018) within a contemptive scrounger narrative (Wincup \& Monaghan, 2016) that questions their societal worth and place (Monaghan \& Yeomans, 2016). A narrative often associated with dependence (on welfare, on substances, on housing, healthcare and other state institutions) that has no place in a neoliberal society (Bauman, 2001). Grounded in their analysis of a UK based reality TV show, Atkinson and Sumnall $(2018, p .1)$ argue that this application of neo-liberal rhetoric frames working class drug users as failing to meet the neoliberal notion of the productive citizen' whilst the 'structural causes of substance use and inequality were silenced, and an emphasis on individual responsibility prioritised'.

Consequently, the only responsible choice in relation to illegal drugs is to 'just say no' with attempts to encourage more informed choices amongst those who say 'yes' responded to in the media with contempt and ridicule (Taylor, 2016). Instead, the media blames the flawed intoxication practices of marginalised populations for ruining people's lives, communities, town centres and businesses (e.g. Cooper, 2018; Doward, 2017; ITV News, 2015). Intoxicated users of illegal substances are framed in media discourses as dehumanised agents of irresponsibility, but also as the zombies, monsters and demons plaguing, corrupting and causing fear in contemporary society (e.g. Alexandrescu, 2019, Cooper, 2018; Gregory, 2018; Thornton, 2018;). Simultaneously, the systemic causes underpinning these ills are disavowed and the ideological emphasis on self-governance is reiterated and reinforced. 
As such, the flawed choices of the intoxicated are constructed as falling 'outside of righteous and respectable consumption' (Measham \& Moore, 2008, p.276). Hence, they need to be 'blamed and shamed...scapegoated and stigmatised for their behaviours in public, media and political discourse' (Atkinson \& Sumnall, 2018, p.2). This process serves two purposes. Firstly, it ascribes cultural boundaries to (licit and illicit) intoxication (Presdee, 2000). These boundaries align with the arbitrary drug apartheid (Taylor et al., 2016) - hence certain cultures of intoxication enjoy the privileged impunity of laissez faire consumption practices whilst others become the target of policy advancements which seek to control and change, or failing that exclude and criminalise, such behaviour. Secondly, it legitimises the socio-legal and economic status quo. For whilst the media unfavourably depict those who consume legal substances inappropriately (to excess, within incorrect places), the corporate respectability and profitability of the alcohol industry legitimises legal regulation. Illegal substances lack such credentials and perhaps more importantly, their consumers lack any such respectability (Measham \& Moore, 2008). Consequently, the media deflect attention away from the destructive practices of legitimate industry whilst simultaneously framing drug prohibition as essentialism (Taylor, 2016). This legitimises the continued marginalisation and criminalisation of the irresponsibly intoxicated consumer (regardless of the legality of the substance used).

\section{The irresponsibly intoxicated consumer}

In the hyper-masculine Western or action movie genres, intoxication is something rarely experienced by the lead (male) character - they drink whisky and vodka martinis galore, but never fall from their horse or out of their Aston Martin. Their alcohol use is instead an indicator of their social identity - they are so tough that they are impervious to intoxication (and indeed its potentially harmful effects). In the same way, an epoch of conspicuous consumption sees individuals seek out social recognition through engaging with alcohol (and the NTE more widely) to assist them in their construction of social identity (Ayres \& Treadwell, 2012; Smith, 2014). Gone are the days of walking into a bar and asking for a generic beer, wine or gin. Instead those inhabiting the NTE choose from a plethora of options; requesting a Peroni, Marlborough Sauvignon or Hendricks gin with Fevertree tonic. Preferred brands which are asked for by name, say as much about the persona of the user as they do their taste buds. Increased consumption of Prosecco in the UK (UHY, 2018) has been accompanied by 
promotional events such as 'Fizzy Fridays' the essence of which is to provide (a diluted version of) the celebrity champagne lifestyle to the masses as people seek out their own piece of luxury.

Yet engagement with such consumables is only cool if one remains in control and does not show the lack of responsibility which characterises the intoxicated. So, whilst amassing impressive bar bills is presented in the news media as aspirational (e.g. Binns, 2013; Byrne \& Boyle, 2012; Sporn, 2018; The Telegraph, 2013), being openly intoxicated to the point of embarrassing oneself represents the antithesis of this, even if you are a celebrity (Atkinson, Elliott, Bellis \& Sumnall, 2011), and particularly if you are female (Nichols, 2011). Ironically, whilst such behaviour is posited as undesirable in official discourse and policy (Home Office, 2012), it actually demonstrates a hyperconformity to consumerism (Ayres, 2019; Raymen \& Smith, 2016) as excessive intoxication is integral to leisure, pleasure and 'man-ing up' in contemporary consumer society (Ayres \& Treadwell, 2012; Iwamoto, Cheng, Lee, Takamatsu \& Gordon, 2011; Smith, 2014). The contradiction being that we are encouraged to want 'more, more, more' (Winlow \& Hall, 2016; Žižek, 1997), whilst simultaneously demonstrating restraint and control in the face of such consumer forces and their paradoxical control mechanisms. Hence the need for people to enact an individualised controlled loss of control (Measham, 2004) when engaging with intoxication. Those unwilling to exercise such restraint and regulate their behaviour are publicly branded and vilified in the media (e.g. Burrows, 2017; Couzens, 2018; Tahir, 2018b).

These paradoxical messages reflect the wider contradictions of capitalism (Ayres, 2019). For example, whilst the UK government alcohol policy encourages the continued availability/expansion of products for the responsible consumer/business it simultaneously associates such products with the very themes of problematic consumption and (ir)responsibility which predominate media representations (e.g. disease, risk, crime, violence and disorder) (Hackley, Bengry-Howell, Griffin, Mistral \& Szmigin, 2008; Haydock, 2014a). Hence, policy cuts red tape for responsible business whilst restricting the liberty of the intoxicated other. Resultantly, whilst pop-up prosseco and craft beer bars are permitted to appear in city centres those same locations are subject to Public Space Protection Orders restricting the use of alcohol amongst street drinkers. Simultaneously whilst purveyors of alcohol have been encouraged to remove high strength varieties of cheap lager and cider 
from their shelves due to their association with problematic populations (Sumpter et al., 2016), those same shops have expanded the available range of higher-end alcohol products they stock that cater for the 'right' clientele (Hancock, 2017; Riley, 2016). Here the responsible consumer is encouraged to engage with the newest consumer trends whilst the freedoms of the intoxicated are restricted. Similarly, whilst city centre nightscapes continue to see new venues appearing for the discerning consumer to enjoy, the use of drunk tanks for those who go too far, become intoxicated and in doing so add to the statistics of disorderly conduct, are being piloted (Evans \& Whitehead, 2016; NHS, 2017).

This repression and demonization is perhaps most explicit to those who either refuse or are unable to engage in regulated drug markets. The irresponsibility of these users - who after all needs to engage with illicit intoxication cultures in the face of such a glittering array of legal choices? - is focussed upon via a multi-pronged strategy of control, criminalisation and incarceration. Yet demographical distinctions are again evident here. For example, whilst the Chief Constable of London's Metropolitan Police attempts to simply shame (the otherwise responsible) middle-class cocaine user into ethical sobriety (Siddique, 2018), the criminal justice system proactively coerces working class drug users towards abstinence. Here, the 'problematic behaviours of problematic populations... who exist somewhere outside of the societal mainstream' (Monaghan \& Yeomans, 2016, p.126) remain the focus of policy. Indeed, Alexandrescu (2018, p.363) observes that media representations of drug users act as 'symbolic frames' which 'mark collective identities and shape hierarchies of moral worth' with certain drug using populations presented as 'threat and pollution'. A process that serves to reinforce the established parameters of freedom, reflecting neoliberal governance and control through individual freedom and choice.

\section{Objective violence, civilised consumption and the drug apartheid}

To further understand the significance of the media's framing of the (ir)responsible citizen and intoxicated other we now consider how this represents an integral role in neoliberalism, consumerism and individualisation, ultimately serving three interlinking key purposes. Firstly, it enables the media to establish a clear demarcation of normality providing a platform for the repression of liberty and the implementation of harm via what Žižek (2008) terms 
objective violence. Secondly, media representations underline the juxtaposition between civilised and barbaric consumption with the former celebrated and the latter leading to condemnation and criminalisation. Thirdly, media reporting serves to camouflage the contradictory practices of consumer capitalism reinforcing the exclusionary drug apartheid, which simultaneously embeds and forbids alternative cultures of intoxication, legitimising the capitalist status quo. As such, these three issues require further consideration.

\section{Demarcation of the normal}

Media representation of intoxication is a 'sublime object of ideology' (Žižek, 1989) that 'act as the cultural wallpaper in our lives' (Taylor, 2010, p.97). Such representation is an ideological bluff ignoring reality in subtly conflated ways that are consumed and treated as if they were real by the general population; who know but pretend not to know (Žižek, 1989). In fact, the media representation of drugs and their resultant intoxication has become more real than the reality itself creating a 'simulacrum' of acceptable and unacceptable intoxication that feeds into a media created hyper-reality surrounding the phenomenon (Baudrillard, 1994). It is this media created hyper-reality that generates much of the misinformation, misunderstanding and ambiguity outlined above, while also serving to direct attention away from the contradictions of neo-liberalism and its systemic violence. Thus, the media plays a key role in the symbolisation of normality, portraying acceptable intoxication in a positive, healthy light (e.g. Bosely, 2018; Dodgson, 2018; Jennings, 2018), while anything that deviates from this normality is portrayed in a distorted and manipulated misrepresentation (Cohen, 1972).

The media representation engenders social conformity by illustrating the consequences for those unwilling to abide by societies rules and refrain from flawed consuming. Therefore, media simplification, complicit within a wider reductionist discourse espoused by politicians, commercial enterprise, researchers and the public alike, ignores the underlying structural causes of intoxication in favour of blaming individuals. The media attributes many of society's ills to the intoxicated other, the flawed consumer who has lost control, while disavowing the systemic violence arising from consumer capitalism, which is imperceptible and in turn explains much of the subjective violence focused on by the media (Taylor, 2010; Žižek, 2008). 
Media representation of the intoxicated not only supports subjective violence, but should also be seen as a form of objective violence. The symbolic violence of the media is embodied in its discourse and representation, while the systemic 'structural' violence arising from consumer capitalism and its ever-expanding market is hidden and negated (Žižek, 2002). The onus on individuals to regulate their behaviour, monitor their own freedoms and to guard against risk is emulated in the micro-control mechanisms implemented to regulate and prevent flawed intoxication. From the no drinking signs on the streets of town centres reinforced by the onthe-spot penalty fines and the creation of zones of exclusion, to the criminalisation of certain forms of intoxication, these controls, although justified on the grounds of 'chaos' and 'carnage' as depicted in the media are discriminatory. They disproportionately discriminate along the lines of gender, race, ethnicity and social class inflicting structurally embedded harms on already disadvantaged groups as control mechanisms, are increasingly, but 'surreptitiously woven into the very fabric of the city' (Hayward, 2004, p.138), differentiating the civilised from the barbaric.

\section{Civilised and barbaric consumption}

Media representation ignores the barbarism of consumer capitalism and its ability to produce 'cultural forms and identities that are closed, intolerant and violent, and, as such, constitute a threat to civilised life' (Hall \& Winlow, 2004, p.277). The persuasive power of the media ignores these harmful subjectivities whilst portraying the 'visceral and occasionally violent' way excluded people are attempting to conform to the values of pseudo-pacified consumer capitalism (Hall \& Winlow, 2004) as problematic, unwanted and undesirable. Resultantly, the media demarcates civilised consumption of intoxicating substances and civilised consumers along demographical lines. However, the substance use of the bourgeoise is preserved and promoted since they can be trusted to act like responsible citizens and implement the necessary controlled loss of control demanded by neoliberal consumerism. Wealthier customers are not only a better class of clientele that represent the 'ideal drinking style', but they have a 'civilising effect' while also increasing profits. Not only do they attract the right kind of people, but they encourage or shame the uncivilised into buying expensive and civilised intoxicants as everyone competes to stand out, fit in and elicit envy (Haydock, 2014b; 
Smith, 2014; Winlow \& Hall, 2016). Meanwhile the substance use of the uber wealthy remains hidden both from plain sight, but also from the media's gaze, as the market offers access to exclusive private members clubs and chauffer driven cars accessed through underground car parks, ensuring a blanket of public invisibility for their (excessive) intoxication practices.

Consumer capitalism therefore demands that we must consume excessively, although only in a civilised and non-risky way, from the array of commodified substances offered, or risk being labelled as flawed and intoxicated consumers (Bauman, 2007). Scapegoating hides the fact that many of society's ills are not a consequence of the intoxicated other but the intensification of neoliberal consumer capitalism, its consequential disintegration of the underlying order (Hall \& Winlow, 2015; Winlow \& Hall, 2016), and its ideological thuggery (Angell, 2000). The depiction of flawed consumers and intoxication in the media as the uncivilised other means these intoxicated 'savages' deserve everything they get, and have no place in a civilised society, creating a clear demarcation between us (the civilised) and them (the barbarians) which feeds into the existing system of drug apartheid.

\section{Drug apartheid}

The media clearly segregates between what constitutes illegitimate and legitimate, barbaric and civilised intoxication, ascribing to the dominant philosophy based on legal status (illegal drugs are bad and thus criminal, while legal drugs are acceptable and thus civilised), method and level of use (extreme intoxication, problematic and dependent patterns of substance use regardless of legal status is bad and should be prohibited). However, this demarcation is not premised on science or harm, instead as Ayres $(2017,2019)$ has argued, it is about prioritising the exigencies of capitalism and corporate profits as many of the benefits ascribed to legitimate substances permitted for civilised intoxication are erroneous and their harmfulness denied and concealed, partly by the media's ideological function.

Alcohol is a good example - we see the symbolic framing of alcohol according to social class and age, social grouping of users and types of drink. Media representations of unacceptable (binge drinking induced) intoxication sit on par with the framing of illegal drugs and their users, as dependent drinkers face coerced sobriety, enforced by surveillance technology (Agerholm, 2017; BBC, 2016), mimicking sanctions already imposed on illicit drug using 
offenders. Meanwhile the civilised consumption of the respectable middle classes, who drink wine or craft beer, is portrayed as healthy, even medicinal, and yet they are most likely to engage in harmful drinking practices (Brierley-Jones et al., 2014; I parraguirre, 2015). Here the drug apartheid allows us to differentiate between appropriate and inappropriate drug consumption and to develop a system of control that results in the exclusion of flawed consumers.

The excommunication of flawed consumers, the 'collateral casualties' of these inherent contradictions, offers a solution to the social-ills identified in the media's reductionist discourse as the other becomes an 'object of ethical responsibility and moral concern' (Bauman, 2007, p.92). Thus, the drug apartheid is constructed along the lines of vested economic interest and moralistic virtue rather than scientific evidence of harm, resulting in the oppression of ostracised consumers. Concurrently, the media sustains the political, economic and moral status quo underpinning the consumer market and its drive for profit. It is this culmination which results in an arbitrary system that allows commercial interests to flourish, the causes of harm to be camouflaged and the intoxicated other to be excluded and criminalised as for example, alcohol related problems are ascribed to 'drinkers themselves and not to the availability of alcohol' (Mercile, 2016, p.62). Thus, the drug apartheid allows for both the cultural inclusion and accommodation of intoxication, whilst simultaneously ensuring the exclusion and stigmatisation of the intoxicated. Similar to Linnemann's (2016) concept of 'governing through meth', the media depiction of intoxication, has created an imaginary that is then substituted for the truth. Consequently, this hyperreality is used to justify control mechanisms that govern individual consumption and criminalise unacceptable modes of intoxication that supposedly cause harm to others, while the systemic harms of consumer capitalism are disavowed.

\section{Conclusion}

Media representations transcend the boundaries of legality, with the predominant focus on the irresponsible outcome of intoxication rather than the legal status of the substance consumed. Flawed consumers, drawn from a lower order of drug using bodies (Alexandrescu, 2018), warrant media condemnation and vilification. The media depicts forms of subjective violence as caused by the intoxicated other, rather than acknowledging the systemic harm 
that underpins much of the subjective violence in the media. According to the media, the intoxicated other needs to be controlled or excluded since they ruin it for everyone and threaten civilised ways of life.

A clear demarcation is established between acceptable and unacceptable intoxication. On one side, sensible, pro-social, desirable. On the other, reckless, anti-social and threatening. Whilst the majority therefore enjoy a good time through responsible drug use, the minority are a risk to the creative consumerist experience that the rest of society depends on for pleasure, leisure and indeed social distinction. The majority are able to responsibly navigate consumerism, and the intoxicated cannot be allowed to ruin it for us all. Yet framing these problematic outcomes as personal failings takes attention away from those industries who manufacture these harms therefore legitimising consumer capitalism and reinforcing the arbitrary nature of contemporary drug regulation and prohibition; an illusion perpetuated by the media as the intoxicated other is merely obeying the 'siren calls of commodified hedonism' (Smith, 2014, p.159).

Whilst heroin users have consistently maintained a position as fallen and flawed individuals, they have been joined by binge drinkers and pregnant mothers who smoke as irresponsible social pariahs. This process of framing those who use certain substances in certain ways as flawed consumers serves a functional Durkeimian purpose as it constructs those who enjoy the good life in a restraining and reasonable manner as viable members of society, whilst those who are unable to demonstrate such restraint are othered and warrant control attracting state intervention. The media therefore dutifully reinforce the dominant status quo and rhetoric espoused by politicians, as they partake in a 'sublime object of ideology' (Žižek, 1989). As such it detracts from the contradictions and systemic violence of neoliberal consumer capitalism and its inherent paradoxes, which feed into the fantasy that to fix these contradictions, the intoxicated other that 'wants to steal our enjoyment (by ruining our way of life)' (Žižek, 1993, p. 203), must be excluded. Resultantly, we all partake in what Mark Fisher (2009) terms 'Capital Realism' and the perpetuation of an innately violent system that prioritises profit over its people (Chomsky, 1999). 


\section{References}

Agerholm, H. (2017, October 12). Criminals could be banned from drinking after they are released from prison. The Independent. Retrieved from

https://www.independent.co.uk/news/uk/home-news/criminals-banned-drinking-releaseprison-probation-officers-gambling-online-content-a7997126.html

Alexandrescu, L. (2019). Streets of the 'spice zombies': Dependence and poverty stigma in times of austerity. Crime Media Culture, 1-17, DOI: 10.1177/1741659019835274.

Alexandrescu, L. (2018). Ethnobotanicals' and 'Spice zombies': new psychoactive substances in the mainstream media. Drugs: Education, Prevention and Policy, 25(4), 356-364.

Angell, I. (2000). The New Barbarian Manifesto. London: Kogan Page.

Atkinson, A., Elliott, G., Bellis, M., \& Sumnall, H. (2011). Young people, alcohol and the media. York: Joseph Rowntree Foundation.

Atkinson, A., \& Sumnall, H. (2018). Neo-liberal discourse of substance use in the UK reality TV show, The Jeremy Kyle Show. Drugs: Education, Prevention and Policy, DOI: 10.1080/09687637.2018.1498456.

Ayres, T.C. (2017). Drugs, Leisure, Consumption and Harm. BSC Newsletter (Winter Edition), 20-26.

Ayres, T.C. (2019). Substance Use in the Night-Time Economy: Deviant Leisure? In O. Smith \& T. Raymen (eds.), Deviant Leisure and Social Harm (pp. TBC). Cambridge: Policy Press.

Ayres, T.C., \& Jewkes, Y. (2012). The haunting spectacle of crystal meth: A media-created mythology? Crime, Media, Culture, 8(3), 315 - 332. 
Ayres, T.C., \& Treadwell, J. (2012). Bars, Drugs and Football Thugs: Cocaine Use amongst English Football Firms. Criminology and Criminal Justice, 12 (1), 83-100.

Bancroft, A. (2009). Drugs, Intoxication and Society. Cambridge: Polity Press.

Baudrillard, J. (1994). Simulcra and Simulation. Michigan: University of Michigan Press.

Bauman, Z. (1997). Postmodernity and its Discontents. Cambridge: Polity.

Bauman, Z. (2001). Consuming Life. Journal of Consumer Culture, 1(1), 9-29.

Bauman, Z. (2007). Consuming Life. Cambridge: Polity.

BBC (2016, February 25). 'Sobriety tags' rollout as $92 \%$ comply in pilot scheme. BBC. Retrieved from https://www.bbc.co.uk/news/uk-england-london-35660946

Bhattacharya, A., Angus, C., Pryce, R., Holmes, J., Bennan, A., \& Mier, P.S. (2018). How dependent is the alcohol industry on heavy drinking in England? Addiction, DOI:10.1111/add.14386.

Binns, D. (2013, October 10). Champagne 'war' in bar leaves tycoons with $£ 131,000$ bill. The Metro. Retrieved from https://metro.co.uk/2013/10/10/champagne-war-in-bar-leavestycoons-with-131000-bill-4142369/

Bosely, S. (2018, February 6). E-cigarettes should be on sale in hospital shops, health body says. The Guardian. Retrieved from

https://www.theguardian.com/society/2018/feb/06/vaping-is-safe-way-to-quit-smokingsays-health-body

Bourne, R. (2012). Minimum alcohol pricing: illogical, illiberal, unfair. Retrieved from https://www.cps.org.uk/blog/q/date/2012/03/23/minimum-alcohol-pricing-illogicalilliberal-unfair/ 
Brierley-Jones, L., Ling, J., McCabe, K.E., Wilson, G.B., Crosland, A., Kaner, E.F., \& Haighton, C.A. (2014). Habitus of home and traditional drinking: a qualitative analysis of reported middle-class alcohol use. Sociology of Health and Fitness, 36(7), 1054-1076.

Burrows, T. (2017, January 1). Some people won't be having a happy new year! Carnage on the streets of Britain as revellers see in 2017 with a night of fighting, vomiting and a LOT of flesh on show. Daily Mail. Retrieved from https://www.dailymail.co.uk/news/article4079616/Some-people-won-t-having-happy-new-year-Carnage-streets-Britain-revellers2017-boozy-night-no-one-s-wrapping-warm.html

Byrne, P., \& Boyle, S. (2012, March 6). Revealed: The big-spending businessman who ran up $£ 203,948$ bar bill was 23-year-old City whizkid. The Mirror 6. Retrieved from https://www.mirror.co.uk/news/uk-news/the-businessman-who-ran-up-203-752576

Chambliss, W.J. (1977). Markets, Profits, Labor, Smack. Contemporary Crises, 1(1), 53-75.

Chomsky, N. (1999). Profit Over People. New York, NY: Seven Stories Press.

Cohen, S. (1972). Folk Devils and Moral Panics: The creation of the Mods and Rockers. Oxford: Basil Blackwood.

Cooper, S. (2018, August 7). Worker fears spice users are making Sheffield city centre unsafe. The Star. Retrieved from https://www.thestar.co.uk/news/worker-fears-spice-users-aremaking-sheffield-city-centre-unsafe-1-9288379

Couzens, G. (2018, January 11). 'Adios!' Passengers cheer as 'drunk and aggressive' Irish couple are escorted off Ryanair flight after they forced it divert to northern Spain. Daily Mail. Retrieved from https://www.dailymail.co.uk/news/article-5257577/Ryanair-flight-divertedremove-drunk-Irish-couple.htm| 
Critcher, C. (2011). Drunken Antics: The Gin Craze, Binge Drinking and the Political Economy of Moral Regulation. In S. Heir S (ed.), Moral Panics and the Politics of Anxiety (pp. 171-189). New York, NY: Routledge.

Day, K., Gough, B., \& McFadden, M. (2004). "Warning! alcohol can seriously damage your feminine health" a discourse analysis of recent British newspaper coverage of women and drinking. Feminist Media Studies, 4(2), 165-83.

Dodgson, L. (2018, September 17). An anti-inflammatory diet, including coffee, chocolate, and red wine, could reduce your chances of dying early, according to new research. The Independent. Retrieved from https://www.independent.co.uk/life-style/health-andfamilies/diet-live-longer-weight-loss-chocolate-wine-beer-anti-inflammatory-a8541816.html

Doward, J. (2017, November 12). The killer on Britain's streets - super-strength alcohol. The Observer. Retrieved from https://www.theguardian.com/society/2017/nov/12/superstrength-cider-lager-killer-on-britain-streets-homelessness-rough-sleepers

Evans, M., \& Whitehead, T. (2013, September 13). Sober up in drunk tank and pay $£ 400$ to leave. The Telegraph. Retrieved from https://www.telegraph.co.uk/news/uknews/law-andorder/10316456/Sober-up-in-drunk-tank-and-pay-400-to-leave.html

Fisher, M. (2009). Capitalist Realism. Ropley: Zero-books.

Gregory, A. (2018, September 12). Save us from this zombie drug hell, pleads MP calling for "decisive action" on spice drug epidemic. The Mirror. Retrieved from https://www.mirror.co.uk/news/politics/theresa-told-must-take-decisive-13233818

Griffin, C., Szmigin, I., Bengry-Howell, A., Hackley, C., \& Mistral, W. (2013). Inhabiting the contradictions: Hypersexual femininity and the culture of intoxication among young women in the UK. Feminism and Psychology, 23(2), 184-206. 
Gunby, C., Carline, A., \& Taylor, S. (2017). Location, Libation and Leisure: An examination of the use of licensed venues to help challenge sexual violence. Crime, Media, Culture, 13(3), 315-333.

Hackley, C., Bengry-Howell, A., Griffin, C., Mistral, W., \& Szmigin, I. (2008). The discursive constitution of the UK alcohol problem in safe, sensible, social: A discussion of policy implications. Drugs: Education, Prevention and Policy, 15(1), 61-74.

Hall, S., \& Winlow, S (2015). Revitilizing Criminological Theory. London: Routledge.

Hall, S., \& Winlow, S. (2004). Crime and violence in the breakdown of the pseudo-pacification process. In J. Ferrell, K. Hayward, W. Morrison, \& M. Presdee (eds.), Cultural Criminology Unleashed (pp. 275-286). London: Glasshouse Press.

Hancock, E. (2017). Supermarket sales soar despite price rises. Retrieved from https://www.thedrinksbusiness.com/2017/11/alcohol-sales-soar-despite-supermarketprices-rising-at-their-highest-rate-in-4-years

Haydock, W. (2014a). The rise and fall of the 'nudge' of minimum unit pricing: The continuity of neoliberalism in alcohol policy in England. Critical Social Policy, 34(2), 260-279.

Haydock, W. (2014b). The 'civilising' effect of a 'balanced' night-time economy for 'better people': class and the cosmopolitan limit in the consumption and regulation of alcohol in Bournemouth. Journal of Policy Research in Tourism, Leisure and Events, 6(2), 172-185.

Hayward, K. (2004). City Limits: Crime, Consumer Culture and the Urban Experience. London: Glasshouse.

Hilton, S., Wood, K., Patterson, C., \& Katikireddi, S. (2014). Implications for alcohol minimum unit pricing advocacy: What can we learn for public health from UK newsprint coverage of key claim-makers in the policy debate? Social Science \& Medicine, 102, 157-164.

Home Office. (2012). The Government's Alcohol Strategy. London: Home Office. 
Hutton, F., Griffin, C., Lyons, A., McCreanor, T., \& Niland, T. (2016). "Tragic girls" and "crack whores": Alcohol, femininity and Facebook. Feminism and Psychology, Vol. 26(1) 73-93. Iparraguirre, J. (2015). Socioeconomic determinants of risk of harmful alcohol drinking among people aged 50 or over in England. BMJ, Open 5, e007684.

Iwamoto, D.K., Cheng, A., Lee, C.S., Takamatsu, S., \& Gordon, D. (2011). "Man-ing" up and getting drunk: the role of masculine norms, alcohol intoxication and alcohol-related problems among college men. Addictive Behaviors, 36(9), 906-11.

ITV News. (2015, February 19). Grieving father of homeless man calls for crack-down on cheap alcohol which ruined his life. ITV News. Retrieved from https://www.itv.com/news/central/2015-02-19/grieving-father-of-homeless-man-calls-forcrack-down-on-cheap-alcohol-which-ruined-his-life/

Jennings, K. (2018, August 17). British MPs push e-cigarettes as health benefit. POLITICO. Retrieved from https://www. politico.eu/article/e-cigarettes-forget-big-tobacco-back-vapingfor-health-benefits-say-mps/

Lennox. J., Emslie, E., Sweeting, H., \& Lyons, A. (2018). The role of alcohol in constructing gender \& class identities among young women in the age of social media. International Journal of Drug Policy, 58, 13-21.

Levy, A. (2010, January 1). New year, same old binge Britain: Arctic weather fails to stop drunken revellers causing chaos on streets of UK. Daily Mail. Retrieved from https://www.dailymail.co.uk/news/article-1239836/New-Year-celebrations-turn-uglyrevellers-drink-excess.html

Linnemann, T. (2016). Meth Wars: Police, Media, Power. New York, NY: New York University Press.

McArdle, H. (2018, November 13). Surge in Buckfast sales blamed on minimum pricing 'trade off' from ciders. Herald Scotland. Retrieved from 
https://www.heraldscotland.com/news/17218694.surge-in-buckfast-sales-blamed-on-

minimum-pricing-trade-off-from-ciders/

Measham, F. (2004). Play space: historical and socio-cultural reflections on drugs, licensed leisure locations, commercialisation and control. International Journal of Drug Policy, 15, 337345.

Measham, F., \& Brain, K. (2005). "Binge" drinking, British alcohol policy and the new culture of intoxication. Crime, Media, Culture, 1(3), 262-283.

Measham, F., \& Moore, K. (2008). The criminalisation of intoxication. In P. Squires (ed.), ASBO Nation: The criminalisation of nuisance (pp. 273-288). Bristol: The Policy Press.

Mercille, J. (2016). Neoliberalism and the alcohol industry in Ireland. Space and Polity, 20(1), 59-74.

Mirowski, P. (2013). Never Let a Serious Crisis Go to Waste: How Neoliberalism Survived the Financial Meltdown. London: Verso.

Monaghan, M., \& Yeomans, H. (2016). Mixing drink and drugs: 'Underclass' politics, the recovery agenda and the partial convergence of English alcohol and drugs policy. International Journal of Drug Policy, 37, 122-128.

NHS (2017). NHS to consider routine use of 'drunk tanks' to ease pressure on A\&Es. Retrieved from https://www.england.nhs.uk/2017/12/drunk-tanks/

Nicholls, J. (2011). UK news reporting of alcohol: An analysis of television and newspaper coverage. Drugs: Education, Prevention and Policy, 18(3), 200-206.

NTIA. (2015). Forward into the Night. London: NTIA. 
O'Hare, S. (2013, January 1). Welcome to 2013: Shameful scenes of booze-fuelled New Year's chaos in cities across Britain. Daily Mail. Retrieved from

https://www.dailymail.co.uk/news/article-2255587/New-Years-Eve-2012-Shameful-scenesbooze-fuelled-chaos-cities-Britain.html

Patterson, C., Emslie, C., Mason, O., Fergie, G., \& Hilton, S. (2016). Content analysis of UK newspaper and online news representations of women's and men's 'binge' drinking: a challenge for communicating evidence-based messages about single-episodic drinking? BMJ, 6, e013124, DOI:10.1136/bmjopen-2016-013124.

Presdee, M. (2000). Cultural Criminology and The Carnival of Crime. London: Routledge.

Pryce, S. (2012). Fixing Drugs: The politics of drug prohibition. Basingstoke: Palgrave MacMillan.

Raymen, T. \& Smith, O. (2016). What's Deviance Got to Do With It? Black Friday Sales, Violence and Hyper-conformity. The British Journal of Criminology, 56(2), 389-405.

Riley, L. (2016). Tesco extends craft beer offering at Express stores. Retrieved from https://www.thegrocer.co.uk/stores/ranging-and-merchandising/tesco-extends-craft-beeroffering-at-express-stores/543682.article

Robinson, M. (2014, January 1). New Year... depressingly familiar scenes: Festivities are marred by drunken revellers causing chaos in towns and cities across Britain. Daily Mail. Retrieved from https://www.dailymail.co.uk/news/article-2532094/Welcome-Britain-2014Shameful-scenes-alcohol-fuelled-New-Years-chaos-spills-towns-cities-Britain.html

Siddique, H. (2018, July 31). Middle-class cocaine users are hypocrites, says Met chief. The Guardian. Retrieved from https://www.theguardian.com/society/2018/jul/31/middle-classcocaine-users-are-hypocrites-says-met-chief-cressida-dick 
Sheron, N., \& Gilmore, I. (2016). Effect of policy, economics, and the changing alcohol marketplace on alcohol related deaths in England and Wales. British Medical Journal, 353, 17.

Smith, O. (2014). Contemporary Adulthood and the Night Time Economy. Basingstoke: Palgrave.

Sporn, N. (2018, February 20). Jay-Z 'racks up impressive $\$ 91,000$ bar bill with $\$ 11,000$ tip'. Evening Standard. Retrieved from https://www.standard.co.uk/showbiz/celebritynews/jayz-racks-up-impressive-91000-bar-bill-with-11000-tip-a3771586.html

Sumpter, C., McGill, E., Dickie, E., Champo, E., Romeri, E., \& Egan, M. (2016). Reducing the Strength: a mixed methods evaluation of alcohol retailers' willingness to voluntarily reduce the availability of low cost, high strength beers and ciders in two UK local authorities. BMC Public Health, 16, 448.

Tahir, T. (2018a, January 3). Happy SPEW Year! Britons see in 2018 with a night of drunken revelry and plenty of flesh on show - followed by violence and lashings of regret as celebrations turn to carnage. Daily Mail. Retrieved from

https://www.dailymail.co.uk/news/article-5225397/Revellers-hit-streets-best-party-outfitsNew-Year.html

Tahir, T. (2018b, June 11). 'Deplorable' passenger forces Jet2 flight to Ibiza to land in France following 'disgraceful' behaviour with blow-up doll in front of children. Daily Mail. Retrieved from

https://www.dailymail.co.uk/news/article-5828807/Passenger-forces-Jet2-flight-divertfollowing-disgraceful-behaviour-blow-doll-in.html

Taylor, P. (2010). Žižek and the Media. Cambridge: Polity.

Taylor, S. (2008). Outside the outsiders: Drugs, drug use and the media. Probation Journal, 55(4), 369-388. 
Taylor, S. (2016). Moving beyond the other: A critique of the reductionist drugs discourse. Tijdschrift over Cultuur and Criminaliteit, 6, 100-118.

Taylor, S., Buchanan, J., \& Ayres, T.C. (2016). Prohibition, privilege and the drug apartheid: The failure of drug policy reform to address the underlying fallacies of drug prohibition. Criminology and Criminal Justice, 16(4), 452-469.

The Telegraph. (2013, January 31). Tamara Ecclestone blows $£ 30,000$ on nightclub champagne bar bill. The Telegraph. Retrieved from

https://www.telegraph.co.uk/news/celebritynews/9838424/Tamara-Ecclestone-blows30000-on-nightclub-champagne-bar-bill.html

Tomkin, S. (2016, January 1). New Year, but the same old shocking scenes: Mayhem in streets across Britain as drunken revellers lose their senses. Daily Mail. Retrieved from https://www.dailymail.co.uk/news/article-3380899/Where-streets-no-shame-New-Yearrevellers-spill-pubs-clubs-night-drunken-excess-Britain.html

Tomsen, S. (1997). A Top Night: Social Protest, Masculinity and the Culture of Drinking Violence. British Journal of Criminology, 37(1), 90-102.

Thornton, L. (2018 September 11). Zombie nation: Britain in grip of spice epidemic as addicts resembling monsters plague streets, scaring children. The Mirror. Retrieved from https://www.mirror.co.uk/news/uk-news/zombie-nation-britain-grip-spice-13229735

UHY. (2018). Increase in UK's sparkling wine market reaches new high - but does slowdown in growth mean we are reaching 'peak Prosecco'? Retrieved from https://www.uhyuk.com/news-events/news/increase-in-uks-sparkling-wine-market-reaches-new-high-butdoes-slowdown-in-growth-mean-we-are-reaching-peak-prosecco/

UKDPC. (2010). Representations of Drug Use and Drug Users in the British Press. London: UKDPC 
Wincup, E., \& Monaghan, M. (2016). Scrounger narratives and dependent drug users: welfare, workfare and warfare. Journal of Poverty and Social Justice, 2(3), 261-275.

Winlow, S., \& Hall, S. (2006). Violent Night: Urban leisure and contemporary culture. Oxford: Berg.

Winlow, S., \& Hall, S. (2016). Criminology and Consumerism. In: Carlen P (ed.) Criminologias Alternativas. Buernos Aries: IEA.

Wood, K., Patterson, C., Katikireddi, S.V., \& Hilton, S. (2014). Harms to 'others' from alcohol consumption in the minimum unit pricing policy debate: a qualitative content analysis of UK newspapers (2005-12). Addiction, 109(4), 578-584.

Žižek, S. (1989). The sublime object of ideology. London: Verso

Žižek, S. (1997). The Plague of Fantasies. London: Verso.

Žižek, S. (2002). Welcome to the Desert of the Real. London: Verso.

Žižek, S. (2008). Violence. New York, NY: Picador.

\section{Author biographies}

Stuart Taylor is Senior Lecturer in Criminal Justice at Liverpool John Moores University, UK. Prior to entering academia Stuart worked for the National Probation Service, latterly specialising in substance use. His main research interests focus on drug use and drug policy with a particular interest in the socio-legal construction of drugs and the role and place of substance use in contemporary society. Recent studies have considered the role of cannabis use and cultivation on a community level and the inferences of using a private drug testing kit amongst a collective of ecstasy users. 
Tammy Ayres is Lecturer in Criminology at the University of Leicester. Tammy has been undertaking research within the field of drugs for almost two decades, with extensive experience of investigating vulnerable populations, particularly problematic drug users, prisoners, people with mental ill-health and trauma both in the community and in prisons. She is co-chair for the British Society of Criminology's Critical Criminology Network and a member of the Deviant Leisure Research Group and the Extreme Anthropology Network.

\footnotetext{
' Inspired by the works of Slavoj Žižek this chapter applies the label of violence to a number of different social behaviours. As such, a brief definition of Žižek's interpretation of these terms is useful as this juncture. Žižek (2008: 9-11) refers to systemic violence as that arising from capitalism and its smooth functioning and alongside symbolic violence, which is embodied in language, constitutes what he refers to as objective violence. Alongside this sits subjective violence which is 'enacted by social agents' and is the most visible form of violence.
} 